\title{
Genetic services in the context of DNA probes: what do they cost?
}

\author{
R BEECH, R J RONA, A V SWAN, F B KAVANAGH, L PRENTICE, \\ O M WILSON, G MOLE, AND P VADERA \\ From the Division of Community Health, United Medical and Dental Schools of Guy's and St Thomas's \\ Hospitals, St Thomas's Campus, London SE1 $7 E H$.
}

SUMMARY We describe results from the first year of a three year economic evaluation of genetic services in the context of DNA probes provided at three genetic centres in Great Britain.

The analysis so far has concentrated on the costs of providing DNA diagnostic services. Estimates are given of the total costs of providing DNA probe services at each of the three centres, together with information for assessing the cost implications of future developments in these services.

DNA probe services are likely to be funded as a Regional specialty. This paper concludes that relative to other developing medical technologies and as an investment by Regions, DNA probe services are inexpensive. An appraisal of the benefits to be derived from DNA probe services is still to be undertaken.

Genetic services in the context of DNA probes are a developing area of medical technology. The aims of this three year study are: (1) to identify the costs and benefits of establishing new centres to provide DNA probe services, and to assess how these costs and benefits are affected by the organisation of centres and the type and level of demand; and (2) to assess how costs and benefits of existing centres will be affected by changes in demand for DNA probe services.

This study therefore makes the assumption that the role of an economic evaluation is not to determine whether DNA probe services should exist, but to provide information to assist the future planning of these services. The primary concern is how are costs and benefits affected by the way in which these services are made more widely available.

The three centres covered by this study are at St Mary's Hospital, Manchester, University Hospital of Wales, Cardiff, and the Institute of Child Health, London. The Departments of Health allocated funds to these centres for a three year Special Medical Development project to develop recombinant DNA technology to the stage where it could be applied routinely in the National Health Service. They provide an interesting mix both in terms of the

Received for publication 16 November 1988. Accepted for publication 1 December 1988. way they organise the provision of DNA probe services and in the types and levels of demand for services they meet.

The centres in Cardiff and Manchester maintain a register containing details of families at risk and have a team of home visit staff who obtain blood samples, whereas in London blood samples are primarily taken by general practitioners (GPs) or when patients visit the centre. In London the range of conditions where DNA probes are being used is much broader than in the other two centres. Finally, the annual number of DNA probe tests, that is, restriction fragment length polymorphisms (RFLPs), varies. During 1987 the number of RFLP analyses performed was 6267 in Manchester, 8954 in Cardiff, and 2902 in London.

The first step in achieving the long term aims of the study was an analysis of the total costs of providing DNA probe services at existing levels of activity: a 'snap-shot' of current costs at current levels of demand. The aim was to identify and cost all of the major functions involved in the provision of DNA probe services, not just the DNA laboratories. This has been the emphasis of the study so far. Estimates of the costs of providing DNA probe services within each of the centres have been derived. In addition, some information is given to assess the impact of changes in demand for DNA probe services on spending in DNA laboratories.

The analysis so far has not considered costs 
related to DNA probes incurred outside genetic centres, for example, obstetric department costs associated with taking a chorionic villus sample.

\section{Methods}

The main recurring costs that can be associated with providing DNA probe services are those of the consumables used in the DNA laboratories, the costs of laboratory staff, clinical staff, register staff, and home visit staff, and the travel costs of home visit staff. The methods used to estimate these costs are now described.

THE COSTS OF CONSUMABLES USED IN DNA LABORATORIES

Although spending on laboratory consumables was likely to be low as a proportion of the overall cost of providing DNA probe services, a detailed analysis of spending in this area was considered important for two reasons. It is spending on consumables that will most immediately be affected by a rise in demand for DNA probe services. It was also considered important to be able to differentiate between conditions when identifying costs.

The aim was to collect information in a form which would allow the following costs by condition to be estimated: current expenditure, future expenditure, and expenditure per DNA analysis report by type of referral, for example, a referral for prenatal diagnosis or for carrier status. A 'building block' of activity was needed which, when costed and multiplied by a given level of activity, would allow the above costs to be estimated. Discussions with staff at the centres identified the RFLP as the appropriate 'building block'.

The figure is a flow chart of the laboratory process. The end product of that process is an RFLP. However, each component can produce a variable number of RFLPs. For example, when DNA has been extracted from human blood, some of it may immediately be used for DNA probe testing but a proportion of it stored for future use when new DNA probes may become available. Similarly, an agarose gel can house between one and 20 samples and the number of RFLPs these produce depends upon how many probes they are hybridised with and the average number of hybridisations that take place.

When identifying RFLP costs by condition, the first step was to cost every stage in the laboratory process. The Manchester centre has written procedures describing the steps involved in the laboratory process and the consumables used. At the two other centres appropriate modifications were made to the procedures before they were costed. Next, the costs

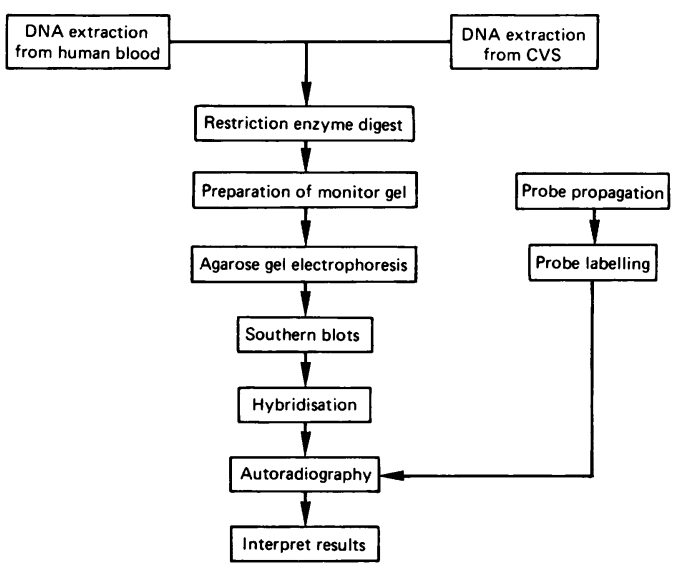

FIGURE Flow chart of laboratory process.

of the various stages of the laboratory process were apportioned to individual RFLPs based upon the $\overrightarrow{0}$ average number of RFLPs they were likely to 0 generate. Overall, RFLP costs by condition were the sum of the RFLP costs for each stage of the laboratory process.

\section{STAFF COSTS OF PROVIDING DNA PROBE} SERVICES

Providing DNA probe services can have a significant impact on the following types of staff within a genetic centre: laboratory staff, clinical staff, register staff, and home visit staff.

Laboratory staff undertake DNA probe testing. Clinical staff are concerned with the diagnosis and counselling of patients. Register staff maintain the register of families at risk and in Manchester also counsel patients. Home visit staff are concerned $\frac{\rho}{\beta}$ with the collection of blood, additional information about families, and counselling.

Firstly the numbers, grades, and employment $\rightarrow$ costs of all staff who contribute in some way to the provision of DNA probe services were identified. N Next, for staff who did not spend all of their time on DNA probe related activities, it was necessary to 0 identify a basis for apportioning the appropriate $\omega$ element of their costs to DNA probe services.

Most laboratory staff solely undertake DNA@ probe related activities, so their costs could be $\Phi$ directly allocated to DNA probe services. No? attempt was made to separate out costs associated ${ }^{0}$ with research to refine DNA probe technology, as

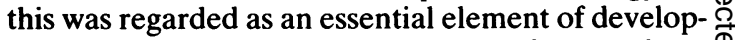

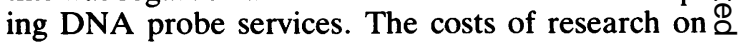
unrelated activities were discarded according to the advice of appropriate staff. For example, in Man- 
chester the costs of a lecturer conducting research related to HLA were excluded.

Clinical, register, and home visit staff do not solely undertake activities related to DNA probe services. Hence methods had to be developed for apportioning the costs of these staff to DNA probe services. Data collected during the first year of the evaluation indicating the average number of home and centre visits required by families for whom DNA is and is not available were used. Because the evaluation only covers one year's data, it was not possible to assess the extent to which DNA probes have increased the number of families referred to the three centres. All that can be assessed at this stage are differences in the intensity of service required by DNA and non-DNA families. The apportionment methods developed regarded these differences as resulting from the existence of DNA probes, based on the assumption that they will increase service intensity because of the need to collect blood samples and transmit the additional information DNA probes provide.

The general methodologies were to apportion clinical staff costs according to the proportion of centre visits resulting from DNA probe services, and home visit staff costs according to the proportion of home visits. Register staff in Manchester were apportioned according to the combined increase in home and centre visits per family owing to DNA probes. Where appropriate, these apportionments were supplemented by staff judgement. Register staff in Cardiff undertake administrative duties and their costs were apportioned to DNA probes based on the advice of the Head of the Genetics Centre.

HOME VISIT TRAVEL COSTS

Total home visit travel costs were based on the annual mileage by home visit staff multiplied by the average reimbursement rate per mile. Costs were apportioned to DNA probe services according to the estimated proportion of visits owing to DNA probes.

\section{Results}

Results are based on 1987 activity costed at March 1988 prices.

\section{ESTIMATED CONSUMABLES COST PER RFLP BY CONDITION}

Columns 1,4 , and 7 of table 1 give consumable costs per RFLP at each of the centres, columns 2, 5, and 8 activity during 1987, and columns 3,6 , and 9 estimated annual expenditure on consumables. The RFLP costs are based upon DNA extracted from human blood because this represents the bulk of

TABLE 1 Laboratory expenditure on consumables and activity by centre.

\begin{tabular}{|c|c|c|c|c|c|c|c|c|c|}
\hline \multirow[t]{2}{*}{ Conditions } & \multicolumn{3}{|l|}{ Manchester } & \multicolumn{3}{|l|}{ London } & \multicolumn{3}{|l|}{ Cardiff } \\
\hline & $\begin{array}{l}\text { Cost/RLFP } \\
\text { (£) }\end{array}$ & $\begin{array}{l}\text { RFLPs } \\
\text { during } \\
1987\end{array}$ & $\begin{array}{l}\text { Estimated } \\
\text { annual } \\
\text { cost }(f)\end{array}$ & $\begin{array}{l}\operatorname{Cos} t / R L F P \\
\text { (f) }\end{array}$ & $\begin{array}{l}\text { RFLPs } \\
\text { during } \\
1987\end{array}$ & $\begin{array}{l}\text { Estimated } \\
\text { annual } \\
\text { cost }(£)\end{array}$ & $\begin{array}{l}\text { Cost/RLFP } \\
\text { (£) }\end{array}$ & $\begin{array}{l}\text { RFLPs } \\
\text { during } \\
1987\end{array}$ & $\begin{array}{l}\text { Estimated } \\
\text { annual } \\
\text { cost }(£)\end{array}$ \\
\hline Haemophilia & $2 \cdot 15$ & 94 & 202 & $2 \cdot 72$ & 146 & 397 & - & - & - \\
\hline Cystic fibrosis & $1 \cdot 81$ & 2352 & 4257 & $2 \cdot 57$ & 523 & 1344 & $1 \cdot 37$ & 1462 & 2003 \\
\hline DMD & 1.44 & 2369 & 3411 & $4 \cdot 03$ & 1022 & 4119 & $1 \cdot 70$ & 2827 & 4806 \\
\hline Myotonic dystrophy & 2.89 & 134 & 387 & $2 \cdot 60$ & 24 & 62 & $2 \cdot 20$ & 1181 & 2598 \\
\hline Jeffries (paternity) & $2 \cdot 21$ & 108 & 239 & $2 \cdot 71$ & 58 & 158 & - & - & - \\
\hline BMD & 1.94 & 36 & 70 & - & - & - & 1.58 & 606 & 957 \\
\hline APKD & 1.99 & 253 & 503 & - & - & - & 1.35 & 146 & 197 \\
\hline Sexing & 1.79 & 15 & 27 & 1.57 & 79 & 124 & - & - & - \\
\hline AED & - & - & - & - & - & - & 1.64 & 264 & 684 \\
\hline $\mathbf{X m m}$ & - & - & - & - & - & - & 1.78 & 201 & 358 \\
\hline Fabry's & - & - & - & - & - & - & 0.86 & 130 & 112 \\
\hline XLA & - & - & - & $3 \cdot 56$ & 81 & 288 & - & - & - \\
\hline Metabolic disorders $\mathrm{X}$ linked & - & - & - & 2.99 & 173 & 517 & - & - & - \\
\hline Cell lines & - & - & - & 2.67 & 20 & 53 & - & - & - \\
\hline HMSN1 & - & - & - & 2.44 & 99 & 241 & 一 & - & - \\
\hline Norrie's & - & - & - & $2 \cdot 58$ & 3 & 8 & - & - & - \\
\hline OTC & - & - & - & $3 \cdot 32$ & 64 & 213 & - & - & - \\
\hline Stickler's & - & - & - & $2 \cdot 67$ & 219 & 585 & - & - & - \\
\hline Scanning $X$ chrom & - & - & - & $2 \cdot 47$ & 22 & 54 & - & - & - \\
\hline NDI & - & - & - & $2 \cdot 55$ & 314 & 801 & - & - & - \\
\hline FG & - & - & - & $2 \cdot 45$ & 21 & 51 & - & - & - \\
\hline Total & & 6267 & 11089 & & 2902 & 9099 & & 8954 & 14108 \\
\hline
\end{tabular}

$\mathrm{DMD}=$ Duchenne muscular dystrophy. $\mathrm{BMD}=\mathrm{Becker}$ muscular dystrophy. $\mathrm{APKD}=$ adult polycystic kidney disease. $\mathrm{AED}=$ anhidrotic ectodermal dysplasia. $\mathrm{Xmm}=\mathrm{X}$ linked myotubular myopathy. $\mathrm{XLA}=\mathrm{X}$ linked agammaglobulinaemia. HMSN1=hereditary motor and sensory neuropathy. OTC=ornithine transcarbamylase deficiency. $\mathrm{NDI}=$ nephrogenic diabetes insipidus. $\mathrm{FG}=\mathrm{FG}$ syndrome. 
laboratory activity at present. During 1987 DNA from CVS accounted for only $3.3 \%, 2.9 \%$, and $2.3 \%$ of extractions at Cardiff, Manchester, and London, respectively.

Differences between the centres in unit costs per RFLP for the same condition are the result of either differences in the costs of each stage of laboratory process or in the number of RFLPs each stage of the process generates. Differences between conditions in costs per RFLP are the result of the restriction enzyme used and the number of RFLPs each stage of the laboratory process generates.

Although costs differ between centres, the general picture is that RFLP costs by condition are small. London undertakes DNA probe testing for the widest range of conditions, possibly reflecting a greater interest in developing services for less common conditions.

Although RFLP tests using DNA extracted from CVS currently account for only a small component of laboratory activity, this type of testing is likely to become more common in the future. In Cardiff, a small sample of data was available to derive preliminary estimates of CVS RFLP costs for cystic fibrosis and Huntington's chorea. These were $£ 1.21$ and $£ 1 \cdot 79$, respectively. For cystic fibrosis, RFLP costs based on blood and CVS were found to be similar, while for Huntington's chorea the CVS costs were around $60 \%$ higher. This was largely because less intensive use was made of the laboratory process because samples needed to be processed urgently. Anecdotal evidence suggests this second example is likely to be the most common and in general CVS RFLP costs will be higher.

\section{ESTIMATED TOTAL COSTS OF DNA PROBE SERVICES}

Columns 1,3 , and 5 of table 2 give annual expenditure on staff in the various groups who $\omega$ contribute to the provision of DNA probe services, but before any apportionment of their time. Total unapportioned home visit travel costs are based on

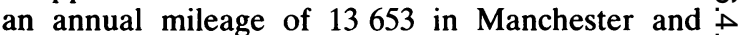
21366 in Cardiff, multiplied by an average allow- N ance of $£ 0.26$ per mile for the two centres. There are $V$ very few home visits in London. Annual expenditure on consumables is the sum of columns 3,6 , and 9 of table 1. Laboratory overheads represent an allow- $\frac{7}{0}$ ance for items such as maintenance contracts and general replacement of minor capital items. These $\vec{\bullet}$ costs estimates were based on data held in the laboratories supplemented by the judgements of staff.

Columns 2, 4, and 6 of table 2 give estimated annual expenditure attributable to DNA probe services. All laboratory consumable and overhead

TABLE 2 Estimated annual costs of DNA probe services at each centre.

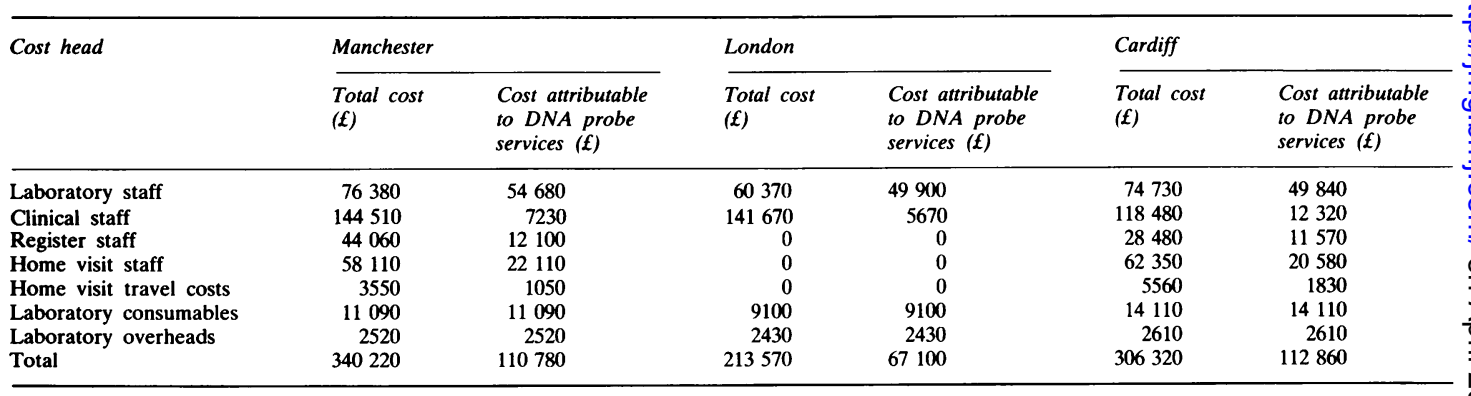

TABLE 3 Manchester visits to the centre and home in new and old referrals by mode of inheritance and availability of $\stackrel{N}{\odot}$ DNA samples.

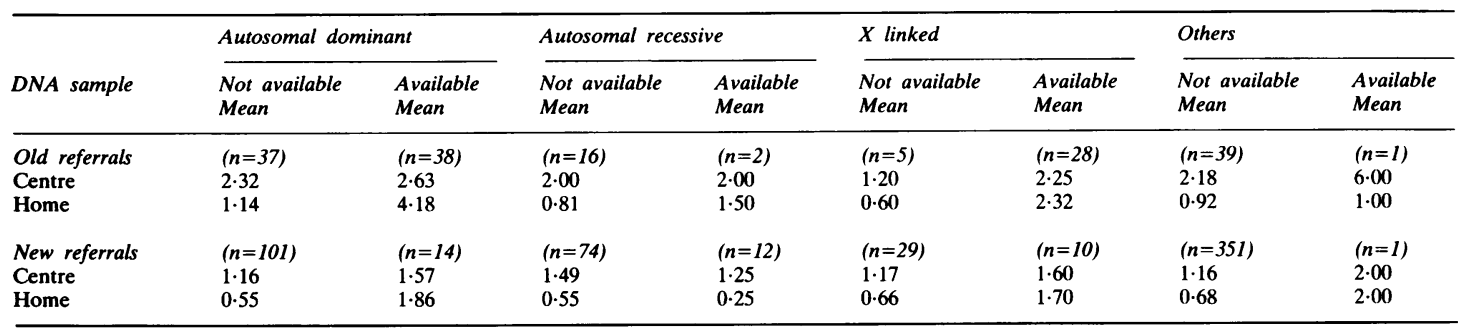


TABLE 4 London visits to the centre and home in new and old referrals by mode of inheritance and availability of DNA samples.

\begin{tabular}{|c|c|c|c|c|c|c|c|c|}
\hline \multirow[b]{2}{*}{ DNA sample } & \multicolumn{2}{|c|}{ Autosomal dominant } & \multicolumn{2}{|c|}{ Autosomal recessive } & \multicolumn{2}{|l|}{$X$ linked } & \multicolumn{2}{|l|}{ Others } \\
\hline & $\begin{array}{l}\text { Not available } \\
\text { Mean }\end{array}$ & $\begin{array}{l}\text { Available } \\
\text { Mean }\end{array}$ & $\begin{array}{l}\text { Not available } \\
\text { Mean }\end{array}$ & $\begin{array}{l}\text { Available } \\
\text { Mean }\end{array}$ & $\begin{array}{l}\text { Not available } \\
\text { Mean }\end{array}$ & $\begin{array}{l}\text { Available } \\
\text { Mean }\end{array}$ & $\begin{array}{l}\text { Not available } \\
\text { Mean }\end{array}$ & $\begin{array}{l}\text { Available } \\
\text { Mean }\end{array}$ \\
\hline Old referrals & $(n=23)$ & $(n=13)$ & $(n=18)$ & $(n=4)$ & $(n=8)$ & $(n=39)$ & $(n=46)$ & $(n=0)$ \\
\hline Centre & $2 \cdot 26$ & 1.92 & 1.50 & $1 \cdot 75$ & 1.75 & 1.72 & 1.65 & 0.00 \\
\hline Home & 0.00 & $0 \cdot 15$ & 0.00 & 0.00 & 0.00 & 0.33 & 0.00 & 0.00 \\
\hline New referrals & $(n=108)$ & $(n=11)$ & $(n=105)$ & $(n=30)$ & $(n=23)$ & $(n=35)$ & $(n=229)$ & $(n=0)$ \\
\hline Centre & 1.07 & 1.46 & 1.08 & 1.50 & 1.30 & 1.89 & 1.07 & 0.00 \\
\hline Home & $0 \cdot 00$ & 0.00 & 0.00 & 0.00 & 0.00 & 0.03 & 0.00 & 0.00 \\
\hline
\end{tabular}

TABLE 5 Cardiff visits to the centre and home in new and old referrals by mode of inheritance and availability of DNA samples.

\begin{tabular}{|c|c|c|c|c|c|c|c|c|}
\hline \multirow[b]{2}{*}{ DNA sample } & \multicolumn{2}{|c|}{ Autosomal dominant } & \multicolumn{2}{|c|}{ Autosomal recessive } & \multicolumn{2}{|l|}{$X$ linked } & \multicolumn{2}{|l|}{ Others } \\
\hline & $\begin{array}{l}\text { Not available } \\
\text { Mean }\end{array}$ & $\begin{array}{l}\text { Available } \\
\text { Mean }\end{array}$ & $\begin{array}{l}\text { Not available } \\
\text { Mean }\end{array}$ & $\begin{array}{l}\text { Available } \\
\text { Mean }\end{array}$ & $\begin{array}{l}\text { Not available } \\
\text { Mean }\end{array}$ & $\begin{array}{l}\text { Available } \\
\text { Mean }\end{array}$ & $\begin{array}{l}\text { Not available } \\
\text { Mean }\end{array}$ & $\begin{array}{l}\text { Available } \\
\text { Mean }\end{array}$ \\
\hline Old referrals & $(n=24)$ & $(n=38)$ & $(n=17)$ & $(n=0)$ & $(n=9)$ & $(n=44)$ & $(n=26)$ & $(n=1)$ \\
\hline Centre & 1.88 & $2 \cdot 84$ & $2 \cdot 18$ & 0.00 & 1.89 & $2 \cdot 16$ & $2 \cdot 08$ & $4 \cdot 00$ \\
\hline Home & 0.38 & $2 \cdot 76$ & $0 \cdot 00$ & $0 \cdot 00$ & $0 \cdot 22$ & 1.02 & 0.00 & 0.00 \\
\hline New referrals & $(n=60)$ & $(n=23)$ & $(n=48)$ & $(n=5)$ & $(n=20)$ & $(n=24)$ & $(n=450)$ & $(n=7)$ \\
\hline Centre & $1 \cdot 27$ & 1.91 & $1 \cdot 27$ & $1 \cdot 20$ & $1 \cdot 25$ & $1 \cdot 58$ & $1 \cdot 38$ & $1 \cdot 14$ \\
\hline Home & $0 \cdot 03$ & 0.48 & 0.04 & 0.20 & 0.15 & 0.46 & 0.03 & 0.29 \\
\hline
\end{tabular}

costs identified are associated with DNA probe services. For staff and home visit travel, some apportionment of costs was necessary. Tables 3, 4, and 5 give data used in staff apportionments, indicating centre and home visits over a year by families for whom DNA is and is not available.

The laboratory staff establishment in Manchester consists of a Senior Lecturer, a Senior Scientist, three Basic Scientists, and a part time secretary. The Professor of Medical Genetics estimated that $50 \%$ of the time of the Senior Lecturer was spent on nonDNA related activities, and the Head of the Laboratory estimated that $75 \%$ of the time of one of the Basic Scientists was spent doing non-DNA related research. All other costs were directly related to DNA probe services.

In London, laboratory staff include a Senior Lecturer, a Senior Scientist, and a Chief Scientific Officer. There are no Basic Scientists. The Chief Scientific Officer estimated that $70 \%$ of his work was unrelated to DNA probe services. All other laboratory staff costs were apportioned to DNA probe services.

Laboratory staff in Cardiff include three Senior Scientists, a Scientist, and two Technicians. On the advice of the Head of the Laboratory, all costs were apportioned to DNA probe services with the exception of $85 \%$ of the costs of two Senior Scientists.

Most other staff apportionments were based on the estimated impact DNA probes have had on the intensity of service required by families, calculated using the data in tables 3,4 , and 5 . Consider visits per autosomal dominant family by families known to the Manchester centre before the start of this evaluation. The 37 families for whom DNA is not available required 2.32 centre visits per family ( 86 visits), and the 38 families for whom DNA is available 2.63 visits per family (100 visits). The method of apportionment assumed that the increase of 0.31 in the average visits per family was the result of DNA probes, that is, 12 of the 186 visits. Hence, in this example, $6.4 \%$ of costs would have been apportioned to DNA probe services.

Clinical staff costs were apportioned to DNA probe services according to the extra visits required to the genetics centres per family owing to DNA technology. The clinical staff team in Manchester includes a Professor, 2.1 Whole Time Equivalent Consultants, a Senior Registrar, and a Registrar. They cover the general mix of genetic disorders. DNA probes were estimated to have caused a $5 \%$ rise in the number of centre visits per family, hence $5 \%$ of the costs of clinical staff were apportioned to DNA probe services.

In London the clinical team consists of a Professor, a Consultant, a Senior Registrar, and $2 \cdot 4$ Whole Time Equivalent Registrars. Again they serve the general mix of conditions. DNA probes were estimated to have caused a $4 \%$ rise in the number of centre visits. 
The clinical staff in Cardiff consist of a Professor, a Senior Registrar, a Clinical Assistant, and two Clinical Lecturers. Two staff cover autosomal dominant conditions, one both autosomal dominant and $\mathrm{X}$ linked conditions, one autosomal recessive conditions, and one the general mix of conditions. DNA probes were estimated to have increased centre visits by $19 \%$ for autosomal dominant conditions, by $16 \%$ for autosomal dominant and $\mathrm{X}$ linked conditions combined, not at all for autosomal recessive conditions, and by $6 \%$ for the general mix of conditions.

Register staff in Manchester consist of a Community Health Service Officer, a Clinical Medical Officer, and a Basic Scientist. In addition to maintaining the register details of families, they undertake home visiting and counselling. Two staff cover autosomal dominant conditions and one both $\mathrm{X}$ linked and autosomal dominant. Their costs were apportioned to DNA probe services according to the increase in the number of home and centre visits combined owing to DNA probes. For autosomal dominant conditions, DNA probes were estimated as having caused a $25 \%$ rise in the number of visits, and for autosomal dominant and $\mathrm{X}$ linked conditions combined an increase of $29 \%$.

In Cardiff the register staff consist of two computer operatives who undertake administrative duties relating to register families. Their costs were apportioned to DNA probe services on the advice of the Professor of Medical Genetics.

For home visit staff the general methodology for apportioning costs to DNA probe services was according to the impact DNA probes have had on the number of visits required per family. In Manchester there are four home visit staff, consisting of a Senior Scientist, a Basic Scientist, and two Health Visitors. Three cover the general mix of conditions and one covers autosomal dominant and $\mathrm{X}$ linked disorders. DNA probes were estimated as having increased general home visits by $26 \%$, and for autosomal dominant and $\mathrm{X}$ linked conditions combined by $50 \%$. The travel costs of these staff were apportioned to DNA probe services using the same percentages. In addition, Manchester has a phlebotomist who estimated that $75 \%$ of her activities were related to DNA probe services.

In Cardiff there are five home visit staff, four on Health Visitor/Nursing grades and one Research Assistant. They cover the general mix of conditions. Adequate home visit data were not available for apportioning the costs of these staff to DNA probes. On the advice of the Professor, $33 \%$ of home visit costs were apportioned to DNA probe services. Travel costs were apportioned in the same manner.

At current levels of activity, laboratory services
TABLE 6 Laboratory staff costs per RFLP at each centre.

\begin{tabular}{lccc}
\hline & Manchester & London & Cardiff \\
\hline Overall laboratory staff costs & & & \\
per annum (f) & 54680 & 49900 & 49840 \\
Current total RFLPs per annum & 6267 & 2902 & 8954 \\
Overall staff cost per RFLP (f) & 8.72 & $17 \cdot 20$ & $5 \cdot 56$ \\
\hline
\end{tabular}

account for the largest proportion of estimated costs attributable to DNA probe services: Manchester $62 \%$, London $92 \%$, and Cardiff $59 \%$.

The type and level of demand served affects expenditure on laboratory consumables, and also appears to influence unit staff costs in the laboratories. Table 6 gives unit costs per RFLP for laboratory staff at each centre. London has the highest laboratory staff costs per RFLP and Cardiff the smallest, probably reflecting the fact that at higher levels of activity economies of scale are possible because staff on senior grades can be supplemented by those on technical grades.

\section{Discussion}

The long term aims of this economic evaluation are to provide information to support future planning of DNA probe services. The intentions are to assess: how the costs and benefits of new centres to provide DNA probe services are affected by their organisation and the type and level of demand they meet; and how the costs and benefits of existing centres will be affected by changes in demand.

The prerequisite for achieving these aims was an assessment of the total costs of providing DNA probe services at three existing centres. The cost analysis has covered the main functions within centres affected by DNA probe services and has recognised that providing these services involves more than funding a DNA laboratory.

The main potential limitation of the costs analysis surrounds the general methodology for apportioning clinical, register, and home visit staff costs to DNA probe services. This stemmed from this study's current knowledge of the way DNA probes are affecting demand for genetic services. Because the evaluation currently only covers referral data for one year, it was not possible to assess the extent to which DNA probe services have increased the overall number of families referred to the genetic centres. The estimated increase in visits per family owing to DNA probes was assessed.

DNA probes may have already increased the rate at which new families are referred to the genetic centres and if this has been so the methods of apportionment both underestimated the current costs of DNA probe services and the proportionate 
size of its non-laboratory components. The impact on costs of this potential underestimate can be tested by making the unrealistic assumption that all visits generated by families for whom DNA is available were the direct result of DNA probes. This modification in the method of apportionment gives an upper limit on the current costs of DNA probes. It affects clinical costs in all of the centres and register and home visit costs in Manchester. This type of sensitivity analysis could not be applied where staff apportionments were based on judgement and does not need to be applied where costs were directly allocated to DNA probe services. This revised methodology causes the estimated costs of DNA probe services to rise to $£ 153230$ in Manchester, to $£ 96850$ in London, and to $£ 144480$ in Cardiff. The true current costs of DNA probe services will lie somewhere between the above inflated estimates and the costs reported in this paper.

The apportionment methods also assumed that for conditions with the same mode of inheritance, and in some instances for all conditions, the staffing input per family visit was the same. The robustness of this assumption will need to be checked.

The cost analysis undertaken so far does allow some assessment of the recurring costs of establishing new DNA laboratories and of the cost implications of increases in demand within existing laboratories.

The unit of activity in the DNA laboratories is the RFLP. The RFLP demand of laboratories is a function of the conditions for which DNA probe services are to be provided, the mode of inheritance of those conditions, and the average number of RFLPs required per person, which in turn depends upon the type of gene defect. We are still to identify these data but the following hypothetical illustrations show how the RFLP workload of a laboratory might be estimated and the difficulties in deriving these estimates.

Consider prenatal diagnostic services required by cystic fibrosis families who are known to be at risk. If couples only had one affected child, only the parents, the affected child, and the fetus are likely to be tested. If each required four RFLPs, the RFLPs per DNA analysis report would be 16 . In this example, any sensitivity analysis of RFLP workload estimates would focus on the potential number of referrals and the RFLPs per referral rather than the number of persons contacted per referral. For services for Duchenne muscular dystrophy, estimating laboratory workload would be more problematical. The variety of gene defects and the high mutation rates mean that estimating the RFLP workload of a 'typical' referral would be difficult because of variations in the number of persons who would need to be contacted per referral. Furthermore 'typical' referrals might need to be subdivided into those whose main gene defect is either a deletion or a point mutation.

Having estimated the RFLP workload of a laboratory, the data in table 1 give consumable RFLP costs for a wide range of conditions and in table 6 unit staff costs per RFLP. The London costs are probably typical of a small laboratory in a university setting. At higher levels of workload, economies of scale appear to be gained. Further advice on the staffing requirements of a DNA laboratory is found in a recent paper by Kelly et al. ${ }^{1}$ In charge of their laboratory, Kelly et al have a postdoctoral scientist in molecular biology and a graduate technician. Increasing workload will be met by the recruitment of a further technician.

The RFLP costs in this report should not, however, be seen as performance indicators of the relative efficiency with which the centres use resources. As the previous examples illustrate, the laboratory costs of a referral are a function of the unit costs per RFLP and the number of RFLPs that need to be performed. Although unit staffing costs are higher in small laboratories, the greater experience of the staff may mean that fewer RFLPs need to be done per referral.

A new DNA laboratory will also require capital equipment. In a pilot study of the three centres covered by this evaluation, we estimated that at 1985 prices the equipment needed by a laboratory would cost around $£ 60000$, the most significant item being an ultracentrifuge. However, other genetics centres we have since visited dispute the need for an ultracentrifuge. Kelly et $\mathrm{al}^{1}$ estimate that equipment for a new DNA laboratory would only cost around $£ 15000$. Developments in laboratory equipment are occurring: pulse field electrophoresis, DNA extractors, DNA synthesisers, and thermal cycling DNA amplification machines. The interesting issue to explore is the extra precision of testing these extra investments provide. This is something we will investigate when we update our estimates of the capital requirements of a new DNA laboratory.

The remaining costs of establishing new centres would depend upon their policies for organising services. The costs in this report indicate the implications of the differing organisational arrangements of the centres covered by this study.

If demand for services in existing laboratories increased, there would be an immediate impact on consumable expenditure. Based upon the expected increase in RFLPs, the unit costs in table 1 could be used directly to estimate the increase in laboratory 
spending on consumables. Changes in demand will not necessarily have an impact on staff costs. In the short term, increases in demand might result in the same numbers of staff doing more, resulting in a decrease in unit staff costs. In the long term, the increase in demand might be such that extra staff are needed and unit staff costs will rise again.

The thrust of this economic evaluation differs from that of a recent British study by Chapple et al. ${ }^{2}$ By comparing the costs of DNA probe services with the savings on hospital services owing to a reduced incidence of persons with genetic disorders, they addressed the issue of whether DNA probe services should exist. Like Callan ${ }^{3}$ we do not believe that it is feasible for economic analysis to resolve such an issue. Callan thinks that the role of economic analysis is to support the decision making process but not be the dominant factor. We believe that the existence of DNA probe services is not in doubt. The issues to be addressed are whether DNA probe services are effective and the most appropriate means of making these services more widely available, hence the focus of our evaluation, namely to provide information to support the future planning of DNA probe services.

Attempts to justify DNA probe services in terms of the savings they generate also create the impression of an expensive service. Chapple et al undertook their cost savings study because of what they perceived as an urgent need for each Regional Health Authority to compare the costs of DNA probe services with the likely financial savings. Such urgency implies a high cost commitment by Regions. More recently, Chapple ${ }^{4}$ has continued to argue that DNA probe services are an expensive investment while stressing that the potential savings justify the costs.

However, although our study is still in its early stages, the conclusion emerging is that relative to other new medical technologies DNA probe services are an inexpensive investment. Extracorporeal shockwave lithotripsy for the treatment of renal and ureteric stones using the Dornier system is another new medical technology for which the Departments of Health commissioned an evaluation around the time of the start of our study. This treatment involves a capital investment of around $£ 1.20$ million and a recurring investment of $£ 1.01$ million per annum based on a workload of 1200 patients. $^{5}$ Although second generation lithotripters will be less costly, they will still require a substantial investment.

DNA probe services are also likely to be located at regional centres and be funded as regional specialties. South-East Thames RHA currently has a revenue budget of $£ 62$ million for its Regional services. ${ }^{6}$ Hence in that Region, for example, funding DNA probe services would only require a rise in the budget for Regional services of around $0 \cdot 2 \%$ (based upon the costs of DNA probe services in Cardiff).

Although the costs of DNA probe services are likely to rise as demand increases, the conclusion that these services are inexpensive to provide is unlikely to change. However, if a screening programme meant these services were targeted to the total community, a revised assessment of their costs would be required.

The conclusion of this paper does not mean that it is unimportant to assess the benefits to be derived from DNA probe services. For example, we are conducting an analysis of the impact more precise estimates of risk have on the outcome of pregnancies. However, the conclusion of the paper does mean that the need to express benefits in terms of financial savings is less important. The debate regarding the future of DNA probe services should shift from a financial analysis of whether they can be afforded to a discussion of their future organisation and their merits on ethical and clinical grounds.

We are most grateful to Professors $P$ Harper, R Harris, M Pembrey, and Dr M Super for their support in this study and Professor W W Holland for his encouragement. We are indebted to Drs D Donnai, H Hughes, H Kingston, and M Baraitser who provided us with a large percentage of families referred to the centres, Drs $\mathrm{R}$ Elles, $\mathrm{S}$ Malcolm, L Meredith, and A Read who explained the laboratory aspects of DNA testing, and to many others whose advice was much appreciated. The study is funded by the Departments of Health.

\section{References}

1 Kelly KF, Haiters NE, Johnston AW. How to do it: start a DNA diagnostic service. $\mathrm{Br}$ Med $J$ 1988;297:276-8.

2 Chapple JC, Dale R, Evans BG. The new genetics: will it pay its way? Lancet 1987;i:1189-92.

${ }^{3}$ Callan J. The economics of pre-natal screening. Centre for Health Economics Discussion Paper No 42, University of York.

${ }^{4}$ Chapple J. Genetic advance at a price. Health Serv J 25 August 1988: $970-1$.

5 Department of Community Medicine, United Medical and Dental Schools of Guy's and St Thomas's Hospitals. Relative costs and cost effectiveness of extracorporeal shockwave lithotripsy versus percutaneous nephrolithotomy in the treatment of renal and ureteric stones. Report to the Department of Health and Social Security as part of the evaluation of lithotripsy at St Thomas's Hospital, June 1988.

6 South East Thames RHA. Financial allocation policy 1988/89. SETRHA, March 1988.

Correspondence to $\mathrm{Dr} R \mathrm{~J}$ Rona, Division of Community Health, United Medical and Dental Schools of Guy's and St Thomas's Hospitals, St Thomas's Campus, London SE1 7EH. 